\title{
Intercostal Lymph Node
}

National Cancer Institute

\section{Source}

National Cancer Institute. Intercostal Lymph Node. NCI Thesaurus. Code C77652.

A lymph node located in the intercostal space of the thoracic wall. 